\title{
STUDI DAMPAK EL NINO DAN INDIAN OCEAN DIPOLE (IOD) TERHADAP CURAH HUJAN DI PANGKALPINANG
}

\author{
Akhmad Fadholi \\ Stasiun Meteorologi Pangkalpinang \\ ABSTRAK \\ El Nino dan Indian Ocean Dipole (IOD) merupakan fenomena global yang memberikan pengaruh \\ terhadap curah hujan yang terjadi di wilayah Indonesia. Besar kecilnya pengaruh itu beragam dari \\ satu tempat ke tempat yang lain. Di kota Pangkalpinang yang memiliki pola curah hujan monsoon, \\ dilakukan studi tentang dampak EI Nino dan IOD terhadap curah hujan yang terjadi. Dengan \\ menggunakan metode korelasi didapatkan hasil bahwa nilai korelasi antara indeks Dipole Mode \\ dengan anomali curah hujan lebih tinggi dibandingkan dengan indeks Nino 3.4.
}

Kata kunci: El nino, IOD, Curah Hujan, Anomali

\begin{abstract}
El Nino and Indian Ocean Dipole (IOD) is a global phenomenon that gives effect to the rainfall in parts of Indonesia. The size of the effect varied from one place to another. In Pangkalpinang that has monsoon rainfall pattern, conducted research on the impact of EI Nino and IOD on rainfall. Results show correlation between Diople Mode index and rainfall anomaly is greater than correlation between Nino 3.4 index and rainfall anomaly.
\end{abstract}

Key words : El Nino, IOD, rainfall, Anomaly.

\section{Pendahuluan}

Pada umumnya Indonesia memiliki dua musim, yaitu musim hujan dan musim kemarau. Secara umum musim hujan terjadi antara bulan Oktober-Maret dengan puncaknya sekitar bulan Desember sampai Februari, disebabkan Monsun Dingin Asia . Sedangkan musim kemarau terjadi antara bulan April-September dengan puncaknya sekitar bulan Juni sampai Agustus, disebabkan Monsun Dingin Australia. Musim di Indonesia selain dipengaruhi oleh Monsun dan pengaruh lokal, juga dipengaruhi oleh adanya fenomena global, diantaranya sirkulasi Hadley, sirkulasi Walker, El Nino, La Nina, Indian Ocean Dipole dan lainnya.
Variasi cuaca dan iklim sangatlah perlu diperhatikan karena sebagian wilayah Indonesia terletak di Belahan Bumi Utara dan sebagian di Belahan Bumi Selatan.

Meskipun musim hujan dan kemarau terjadi secara periodik, tetapi panjang musim dan jumlah curah hujan untuk setiap musim tidaklah selalu sama. Kondisi ini menunjukkan bahwa musim di wilayah Indonesia tidak hanya dibentuk oleh monsun, tapi dibentuk juga oleh faktor lain yang berinteraksi dengan monsun untuk membentuk musim tersebut (Sulistya et al,2000). Faktor tersebut bisa jadi merupakan fenomena global yaitu El Nino dan Indian Ocean Dipole. Adanya kemungkinan tersebut membuat penulis 
mencoba mengkaji dampak dua fenomena global tersebut terhadap curah hujan di kota Pangkalpinang yang merupakan kota tempat tinggal penulis.

\section{Teori Dasar}

Curah Hujan

Hujan adalah bentuk endapan yang sering dijumpai, dan di Indonesia yang dimaksud dengan endapan adalah curah hujan. Endapan atau presipitasi itu sendiri didefinisikan sebagai bentuk air cair dan padat (es) yang jatuh ke permukaan bumi. Jumlah curah hujan dicatat dalam inci atau milimeter ( 1 inci $=25,4 \mathrm{~mm}$ ). Jumlah curah hujan $1 \mathrm{~mm}$, menunjukkan tinggi air hujan yang menutupi permukaan $1 \mathrm{~mm}$, jika air tersebut tidak meresap ke dalam tanah atau menguap ke atmosfer. (Tjasjono, 2004). Definisi lain dari hujan, hujan (rain) adalah jatuhan-jatuhan hidrometeor yang mencapai tanah berupa partikel-partikel air, berbentuk keping dengan diameter 0,5 mm atau kurang (Soejitno,1973). Musim hujan di Indonesia didefinisikan sebagai periode dengan jumlah curah hujan 150 $\mathrm{mm}$ dalam sebulan, sedangkan musim kemarau didefinisikan sebagai periode dengan jumlah curah hujan $150 \mathrm{~mm}$ dalam sebulan. (BMG,2006).

Variasi curah hujan spasial di Indonesia dibagi menjadi tiga pola (gambar 1). Tiga pola tersebut adalah pola monsunal (5 - 110 S, 101 - 1170 E), pola equatorial $\left(5^{\circ} \mathrm{N}-3^{\circ} \mathrm{S}, 91-99^{\circ} \mathrm{E}\right)+\left(5^{\circ} \mathrm{N}-\right.$ $3^{\circ} \mathrm{S}, 109$ - 1170 E), dan pola lokal (1 - 7o S, 121 - 133。 E). Distribusi series waktu musim curah hujan ditampilkan seperti " $\mathrm{v}$ " or " $u$ " untuk pola monsoon. Dari data observasi bahwa curah hujan minimum terjadi pada Juni dan Juli dan maksimum terjadi pada Desember atau Januari (Bannu, et. al, 2003). Pola ini mewakili hampir sebagian besar di Indonesia seperti Lampung, Jakarta, Ujung Pandang dan Kupang. Pola curah hujan Equatorial mempunyai karakteristik dua puncak curah hujan pada siklus tahunannya. Pola curah hujan lokal mempunyai karakteristik yang unik dan biasanya kebalikan dari pola monsoon.

El Nino
ENSO merupakan fenomena laut dan atmosfer yang terjadi bersama-sama di Pasifik tropis. Dalam kondisi normal, Pasifik barat tropis lebih hangat daripada Pasifik timur. Akibatnya angin equatorial berhembus ke arah barat membantu konveksi di Pasifik barat dan subsidensi di Pasifik timur.

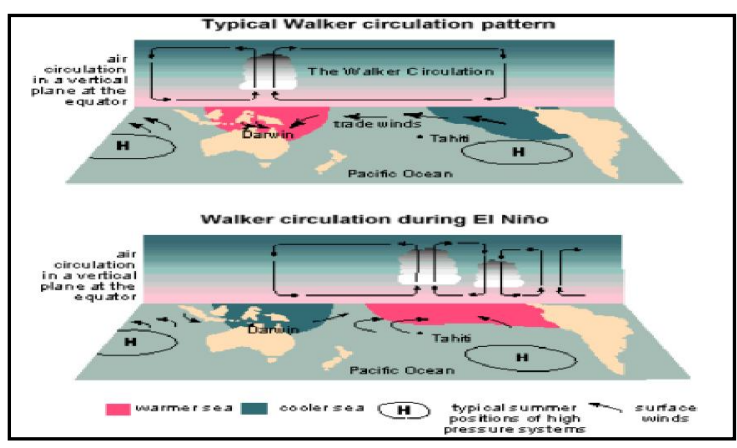

Gambar 1. Skema kondisi normal dan El Nino

Sel sirkulasi vertikal disebut sebagai sirkulasi Walker, yang melengkapi gerak naik di barat dan turun di timur dengan pergerakan ke arah timur di troposfer atas (Gambar 2, panel atas). Perubahan kecil pada pola normal suhu permukaan laut di Pasifik barat menyebabkan perubahan dalam musiman angin permukaan timuran sepanjang ekuator. Perubahan angin biasanya terlihat sebagai anomali baratan yang menguatkan pertumbuhan anomali suhu permukaan laut dan anomali suhu permukaan laut dan angin merambat ke arah timur untuk meningkatkan kondisi El Nino. Selama fase dewasa El Nino, anomali sirkulasi walker muncul berlawanan dengan kondisi normalnya, konveksi di barat ditekan dan di bagian timur menguat. Setelah konveksi menurun di Pasifik barat, El Nino menyebabkan kondisi yang lebih kering di Indonesia (Yulihastin, E, dkk, 2009).

ENSO (El Nino-Southern Oscillation) merupakan salah satu bentuk penyimpangan iklim di Samudera Pasifik yang ditandai dengan kenaikan suhu permukaan laut (SPL) di daerah khatulistiwa bagian Tengah dan Timur. Fenomena tersebut memainkan peranan penting terhadap variasi iklim tahunan. Pengaruh ENSO sangat terasa di beberapa 
wilayah Indonesia yang ditandai dengan jumlah curah hujan lebih kecil dalam tahun ENSO dibandingkan dengan pra dan pasca ENSO, sehingga dapat menyebabkan musim kemarau lebih panjang. Selain dapat mempengaruhi tingginya curah hujan, kejadian El-Nino juga berpengaruh terhadap masuknya musim kemarau. Perubahan iklim akan mengakibatkan perubahan pola iklim tahunan seperti terlambatnya awal musim hujan maupun musim kering. Di samping itu periode musim hujan juga diperkirakan akan lebih pendek (Kailaku, T.E, 2009).

\section{Indian Ocean Dipole}

Selain ENSO, Terjadi pula gejala penyimpangan iklim yang dihasilkan oleh interaksi laut dan atmosfer di Samudera Hindia di sekitar khatulistiwa yang disebut dengan IOD (Indian Ocean Dipole). Interaksi tersebut menghasilkan tekanan tinggi di Samudera Hindia bagian Timur (bagian Selatan Jawa dan Barat Sumatra) yang menimbulkan aliran massa udara yang berhembus ke Barat. Hembusan angin ini akan mendorong massa air di depannya dan mengangkat massa air dari bawah ke permukaan. Akibatnya, SPL di sekitar pantai Selatan Jawa dan pantai Barat Sumatera akan mengalami penurunan yang cukup drastis, sementara di dekat pantai timur Afrika tejadi kenaikan suhu permukaan laut (Kailaku, T.E, 2009).

Indian Ocean Dipole (IOD) adalah kondisi interaksi laut-atmosfer yang terjadi di samudera hindia tropis. Selama fenomena IOD positif (Gambar 3), suhu permukaan laut secara anomali menghangat di Samudera Hindia barat, sedangkan di bagian timur lebih dingin dari normalnya (Saji et al. 1999; Yamagata et al. 2004). Perubahan pada suhu permukaan laut selama IOD terjadi terkait dengan perubahan medan angin di tengah samudera Hindia ekuator. Sehingga angin bergerak berlawanan dari biasanya barat ke timur selama IOD positif. Selain itu, proses konveksi yang biasanya terjadi di atas Samudera Hindia bagian timur yang menghangat bergerak ke arah barat. Hasil dari kondisi tersebut adalah hujan lebat di
Afrika bagian timur dan meninggalkan wilayah Indonesia dengan sedikit hujan (e.g. Bahera et al. 2005, 2007), yang kemudian diikuti dengan kekeringan dan hutan yang terbakar. Fosil koral dari pantai Sumatera mencatat fenomena IOD beberapa kali di Holocene. Terkait dengan perubahan angin dan suhu permukaan laut dan menyerupai fenomena ENSO, kondisi IOD mempengaruhi konveksi di Indonesia dan curah hujan regionalnya (Yulihastin, E, dkk, 2009).

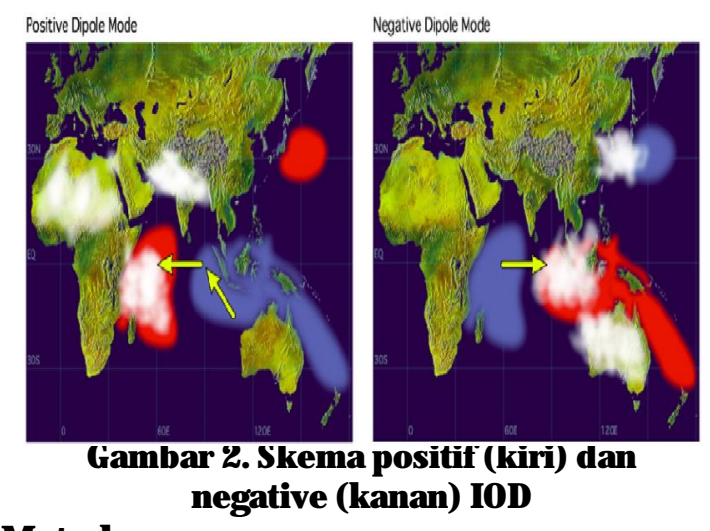

Metode

Studi dampak El Nino dan Indian Ocean Dipole terhadap curah hujan di Pangkalpinang dilakukan dengan menggunakan beberapa data. Data-data tersebut antara lain indeks Nino 3.4, indeks Dipole Mode, dan data curah hujan dari Stasiun Meteorologi Pangkalpinang selama 30 tahun sejak tahun 1981 hingga 2010. Data indeks Nino 3.4 dan Dipole Mode menjadi acuan untuk menentukan tahuntahun di mana terjadi El Nino dan IOD positif.

Tahun-tahun yang telah diketahui menjadi tahun El Nino dan IOD positif kemudian dikaitkan dengan kondisi curah hujan bulanan yang terjadi dengan melihat anomali curah hujan yang terjadi dengan menggunakan rumus :

$$
\text { Ano } \begin{aligned}
C H_{i j} & =C H_{i j}-\overline{C H_{i j}} \\
\overline{C H_{i j}} & =\frac{i}{n} \sum_{j=1}^{n} C H_{j}
\end{aligned}
$$

Keterangan:

Ano $\mathrm{CH}_{\mathrm{ij}}=$ anomali curah hujan di stasiun ke-i bulan ke-j. 
Setelah nilai anomali diketahui maka dikorelasikan dengan nilai indeks Nino 3.4 dan nilai indeks Dipole Mode. Dari nilai korelasi tersebut ditentukan mana yang lebih berpengaruh terhadap anomali curah hujan yang terjadi. Analisis korelasi menggunakan rumus berikut:

$$
r=\frac{n \sum_{i=1}^{n} x_{i} y_{i}-\left(\sum_{i=1}^{n} x_{i}\right)\left(\sum_{i=1}^{n} y_{i}\right)}{\sqrt{\left[n \sum_{i=1}^{n} x^{2} t-\left(\sum x_{i}\right)^{2}\right]\left[n \sum_{i=1}^{n} y^{2} t-\left(\sum y_{i}\right)^{2}\right]}}
$$

Keterangan:

$\mathrm{r}=$ korelasi

$\mathrm{n}=$ jumlah data

$\mathrm{x}=$ ind eks Nino 3.4 atau IOD

$\mathrm{y}=$ anomali curah hujan

Nilai korelasi berkisar antara -1 dan 1. Tanda positif atau negatif menunjukkan arah korelasinya. Bila korelasi antara $\mathrm{x}$ dan $\mathrm{y}$ negatif maka kenaikan variabel $\mathrm{x}$ akan menyebabkan penurunan y atau sebaliknya. Bila korelasi antara $\mathrm{x}$ dan y positif maka kenaikan variabel $\mathrm{x}$ akan diikuti dengan kenaikan variabel y atau sebaliknya.

\section{Analisis dan Inter pretasi}

ENSO dan IOD dua fenomena dominan variasi iklim di Pasifik tropis dan Samudra Hindia. Kedua fenomena ditunjukkan untuk mempengaruhi kondisi iklim dari beberapa tempat di bumi. Terletak di antara dua area tersebut, Indonesia mempunyai iklim yang terkait dengan dua fenomena tersebut. Pada penelitian kali ini, penulis mencoba untuk meneliti pengaruh dari beberapa fase El Nino dan IOD terhadap curah hujan Pangkalpinang. Selama tahun IOD positif, Samudera Hindia bagian timur lebih dingin daripada normalnya sedangkan bagian barat lebih hangat daripada normalnya. Sejak indeks Dipole Mode ditetapkan sebagai perbedaan antara area barat dan area timur, indeks bernilai positif selama tahun IOD positif dan bernilai negative selama tahun IOD negatif. Untuk menentukan tahun-tahun El Nino/La Nina dan positif atau negatif IOD, dilakukan dengan menggunakan data indeks Nino 3.4 dari website NOAA dan indeks Dipole Mode dari website JAMSTEC. Indeks Nino 3.4 dan Dipole Mode bisa dilihat pada gambar dalam bentuk grafik time series sejak tahun 1981 sampai 2010. Pada grafik telah ditandai tahun-tahun yang merupakan tahu terjadinya El Nino dan IOD positif. Tahuntahun di mana terjadi El Nino dan IOD positif secara bersamaan antara lain 19821983, 1994-1995, 1997-1998 dan 20062007 (BoM, 2012). Selain itu juga tahun 2007-2008 yang yang di mana La Nina berbarengan dengan IOD positif (BoM, 2012) di mana La Nina berbarengan dengan IOD positif (BoM, 2012)

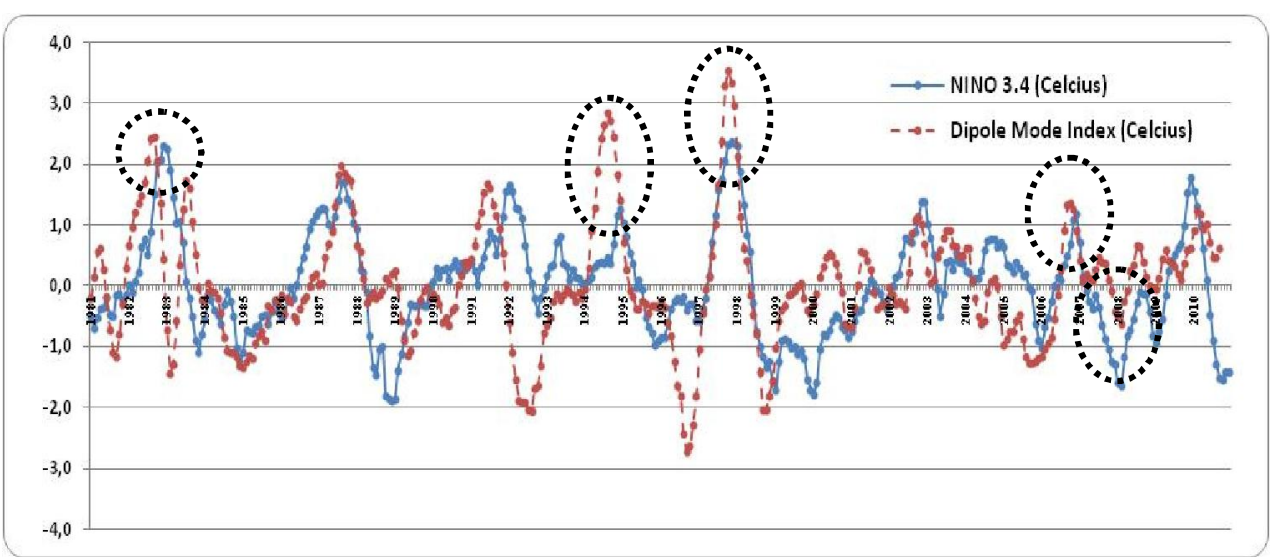

Gambar 3. Anomali indeks Dipole Mode dan Nino 3.4 menunjukkan ada empat kejadian (1982-1983, 1994-1995, 1997-1998, 2006-2007) 
Curah hujan selama 30 tahun dari 1981 sampai 2010 di Pangkalpinang ditampilkan pada gambar 4 yang telah disertai dengan nilai anomali tiap bulannya. Nilai anomali tiap bulan yang ada merupakan salah satu sarana untuk melihat selisih dari curah hujan pada bulan tertentu dengan nilai anomali pada bulan tersebut. Tahun-tahun yang telah ditandai merupakan tahun-tahun yang telah disebutkan sebagai fenomena El Nino dan IOD sebelumnya.

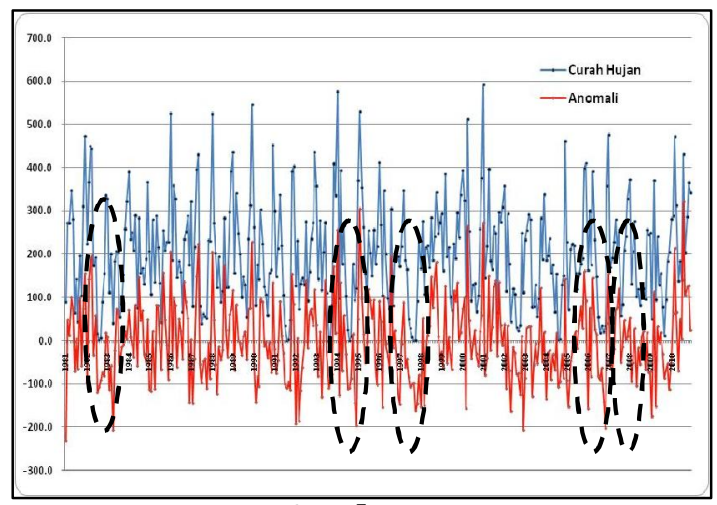

Gambar 4

Identidikasi anomali curah hujan bulanan terkait dengan El Nino dan IOD positif

1. Curah Hujan Selama El Nino and Positive IOD (Januari 1982-Juli 1983)

Curah hujan Pangkalpinang selama El Nino dan IOD positif Januari 1982-Juli 1983 ditunjukkan oleh grafik pada gambar 5. Curah hujan pada tahun 1982 menampilkan sebuah grafik dengan nilai anomali yang memiliki pergerakan sangat mirip dengan curah hujan pada tahun tersebut. Pada tahun ini baik El Nino maupun IOD menurut Ashok dkk (2003) mempunyai intensitas kuat. Menggunakan metode nilai korelasi, didapatkan bahwa nilai korelasi antara indeks Nino 3.4 dengan anomali curah hujan yang terjadi sebesar -0.44 sedangkan indeks Dipole Mode dengan anomali curah hujan sebesar -0.17.

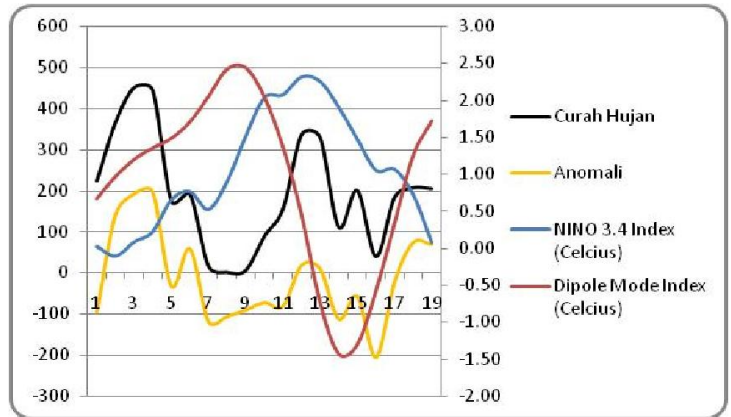

Gambar 5.

Grafik indeks Nino 3.4, indeks IOD, curah hujan bulanan, dan anomali curah hujan saat El Nino dan IOD positif 1982-1983

Dari data yang diperoleh, tercatat indeks Nino 3.4 tertinggi 2.31 pada bulan Desember 1982 dan indeks IOD tertinggi pada bulan September 1982 dengan 2.44. Dari anomali curah hujan yang didapat, pada bulan Juli-November 1982 menunjukkan nilai negatif yang cukup besar yaitu -120.3, -107.6, -92.0, 73.5, dan -82.5 mm. Selain itu, ternyata juga terjadi anomali curah hujan yang signifikan pada bulan Februari-April 1983 dengan nilai -114.7, -58.5, dan $-207.2 \mathrm{~mm}$.

2. Curah Hujan Selama El Nino and Positive IOD (Maret 1994-Februari 1995)

Kondisi curah hujan pada saat kejadian El Nino dan IOD positif tahun 1994-1995 dapat dilihat pada gambar 6. Kondisi kedua indeks pada tahun ini memiliki nilai positif semuanya. Intensitas IOD pada tahun ini lebih kuat dibanding dengan El Nino (Ashok dkk, 2003). Indeks Nino 3.4 tertinggi pada bulan Desember 1994 dengan 1.26 dan Indeks IOD tertinggi pada Agustus 1994 dengan 2,84. Nilai korelasi antara indeks Nino 3.4 dengan anomali curah hujan -0.19 dan korelasi antara indeks Dipole Mode sebesar -0.63. 


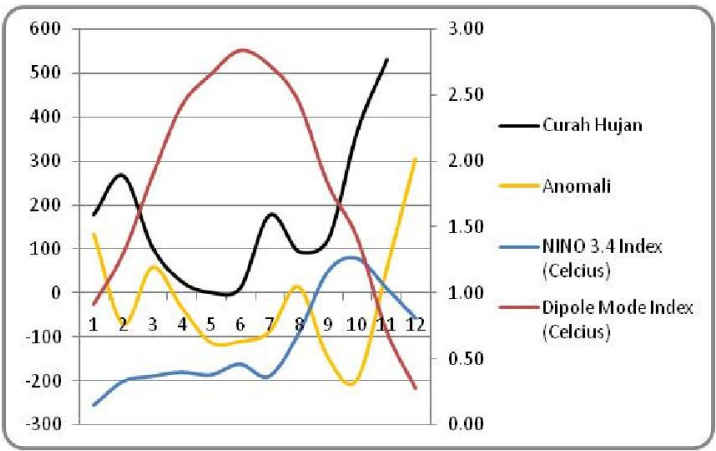

Gambar 6.

Grafik indeks Nino 3.4, indeks IOD, curah hujan bulanan, dan anomali curah hujan saat El Nino dan IOD positif 1994-1995

Pada tahun ini dapat dilihat bahwa kondisi curah hujan bulanan memiliki nilai anomali yang signifikan. Dari awal kejadian sampai akhir, curah hujan memiliki status anomali yang negatif yaitu lebih kecil dari normalnya. Pada bulan Juli, anomali yang terjadi -112,3 mm dan pada bulan Agustus 1994 curah hujan $0 \mathrm{~mm}$. selain itu juga nilai anomali November dan Desember dengan -144.9 dan -197.2 mm. Efek yang terlihat terhadap penurunan curah hujan maupun nilai anomali di Pangkalpinang sangat terlihat.

3. Curah Hujan Selama El Nino and Positive IOD (Juni 1997 - Februari 1998)

Kondisi El Nino paling kuat terjadi pada tahun ini, hampir sebagian besar wilayah Indonesia mengalami penurunan jumlah curah hujan yang signifikan. Namun, selain El Nino yang kuat ternyata ada pengaruh IOD yang sedang positif kuat (Ashok dkk, 2003), sehingga semakin menguatkan efek kering yang terjadi. Pada gambar 7 bisa memperjelas kondisi kering yang terjadi di pangkalpinang. Nilai indeks Nino 3.4 yang terbesar pada bulan November 1997 dengan 2.38, ditambah indeks IOD yang sangat besar yaitu 3.55. Nilai korelasi antara indeks Nino 3.4 dengan anomali curah hujan sebesar -0.35 dan indeks Dipole Mode dengan anomali curah hujan -0.60.

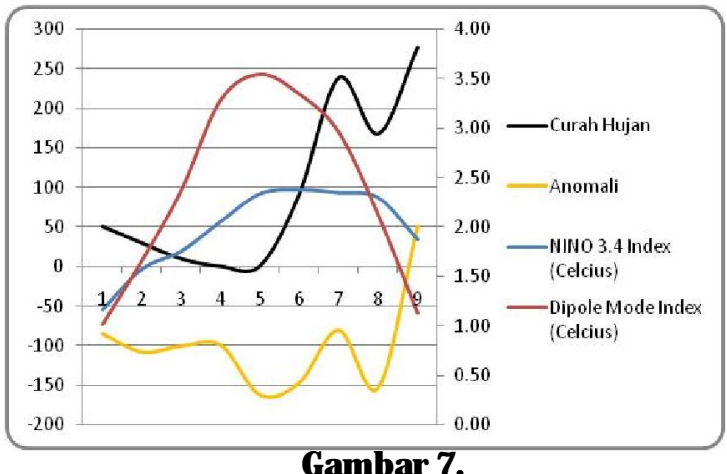

Grafik indeks Nino 3.4, indeks IOD, curah hujan bulanan, dan anomali curah hujan saat El Nino dan IOD positif 1997-1998

Kondisi yang terjadi pada tahun ini mirip dengan yang terjadi pada tahun 1994-1995. Karakteristik nilai indeks IOD setelah diplot ke dalam bentuk grafik menggambarkan hal yang sama dengan tahun sebelumnya. Nilai indeks IOD yang mencapai puncak diikuti oleh curah hujan $0 \mathrm{~mm}$ pada bulan September 1997 dan nilai anomali yang sangat tinggi. Nilai anomali yang terjadi dari bulan Juni 1997 - Januari 1998 yaitu $-84.7,-108.0,-100.6,-99.1, \quad-162.1$, $-146.6,-80.4$, dan $153.3 \mathrm{~mm}$.

4. Curah Hujan Selama El Nino and Positive IOD (Juni 2006-Februari 2007)

Pada tahun 2006 terjadi El Nino yang disertai dengan menguatnya indeks IOD. Nilai indeks Nino 3.4 tertinggi tercatat 1.18 pada Desember 2007 dan indeks IOD terkuat pada Oktober 2006 dengan 1.37. intensitas El Nino pada tahun ini lemah sedangkan terjadi juga IOD yang kuat (Bahera dkk, 2008). Meskipun nilai indeks tidak setinggi tahun-tahun sebelumnya, namun efek yang diakibatkan bisa dilihat pada nilai anomali curah hujan yang terjadi pada gambar 8. Nilai korelasi antara undeks Nino 3.4 dengan anomali curah hujan -0.01 sedangkan indeks Dipole Mode -0.49 . 


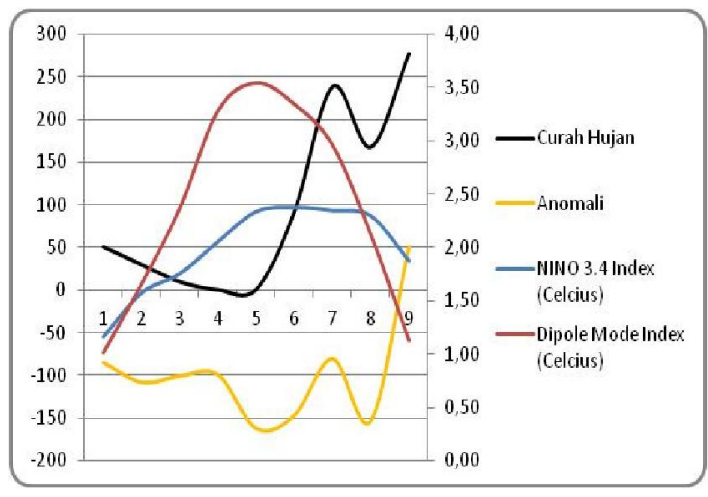

Gambar 8.

Grafik indeks Nino 3.4, indeks IOD, curah hujan bulanan, dan anomali curah hujan saat El Nino dan IOD positif 2006-2007

Kondisi curah hujan bulanan mulai Juli sampai November tahun 2006 mengalami penurunan dibanding dengan normalnya. Anomali pada bulan-bulan tersebut berkisar antara -63.2 pada bulan September hingga $-202.8 \mathrm{~mm}$ pada November. Jika dilihat lebih lanjut, kondisi yang digambarkan pada grafik di atas sangat mirip dengan kejadian El Nino dan IOD pada tahun 1997-1998. Dari semua kondisi El Nino dan IOD secara bersamaan terlihat efek yang jelas ketika bulan-bulan kemarau di Pangkalpinang.

5. Curah Hujan Selama La Nina dan Positive IOD (Juni 2007 - Februari 2008

Hasil yang telah dipaparkan ketika terjadi El Nino dan IOD positif dikaitkan dengan curah hujan tercatat di Pangkapinang, dilanjutkan dengan pembahasan ketika IOD positif berbarengan dengan kejadian La Nina sebagai perbandingan. Pada tahun ini menurut Bahera dkk (2008) terjadi La Nina dengan intensitas sedang dan IOD dengan intensitas kuat. Nilai korelasi antara indeks Nino 3.4 dengan anomali curah hujan sebesar 0.53 sedangkan indeks Dipole Mode sebesar 0.39 . Hasil yang didapat secara lengkap bisa dilihat pada gambar 9 .

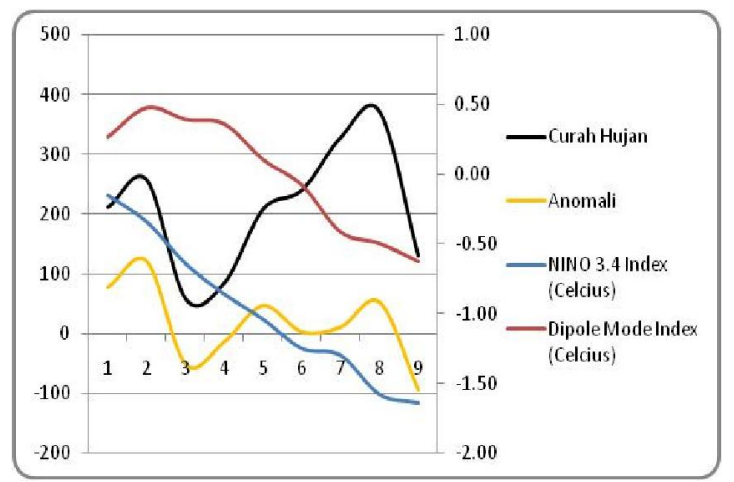

Gambar 9.

Grafik indeks Nino 3.4, indeks IOD, curah hujan bulanan, dan anomali curah hujan saat La Nina dan IOD positif 2007-2008

Nilai indeks Nino 3.4 bergerak turun bersamaan dengan penurunan nilai indeks IOD. Hasil dari kombinasi dua indeks tersebut diindikasikan mempengaruhi dari curah hujan bulanan yang tercatat di Pangkalpinang. Perbedaan dari kasus-kasus sebelumnya, tercatat nilai anomali yang terjadi tidak sebesar dibanding tahun-tahun El Nino dan IOD positif sebelumnya. Anomali berkisar dari -14.3 hingga -94.6 dan kondisi tersebut tidak kontinu. Namun yang menjadi catatan penting, pada bulan Agustus terjadi anomali posistif dengan nilai mencapai $120.3 \mathrm{~mm}$. Hal tersebut perlu dicatat mengingat bulan Agustus pada tahun ini berbeda dengan tahun-tahun kejadian sebelumnya yang mempunyai nilai anomali negative ketika terjadi El Nino dan IOD positif. Lazim terjadi pada bulan Agustus yang merupakan musim kemarau dengan curah hujan relative kecil. Tapi pada tahun La Nina ini tercatat lebih besar sehingga bisa menjadi indikasi perbedaan antara kejadian El Nino dan La Nina yang terjadi di Pangkalpinang.

Kesimpulan Hampir di seluruh kejadian El Nino yang bersamaan dengan Dipole Mode didapatkan nilai korelasi antara indeks Dipole Mode dan anomali curah hujan lebih tinggi dibanding korelasi antara indeks Nino 3.4 dan anomali curah hujan. Hal tersebut sangat 
dimungkinkan karena letak kota Pangkalpinang yang berada di Indonesia bagian barat dan lebih dekat dengan Samudera Hindia. Selain itu juga kondisi El Nino dan IOD positif mempunyai efek yang jelas di Pangkalpinang pada bulanbulan musim kemarau. Dari hasil penelitian ini, masih perlu dikembangkan lagi. Hal ini perlu dilakukan mengingat pokok bahasan pada penelitian ini masih di lingkup ketika El Nino dan IOD positif terjadi, sedangkan belum dilakukan penelitian dampak terhadap curah hujan di Pangkalpinang ketika salah satu indeks menguat atau melemah atau keduanya melemah.

\section{Daftar Pustaka}

Ashok, K., Guan, Z., Yamagata, T. A Look at the Relationship between the ENSO and the Indian Ocean Dipole. Journal of the Meteorological Society of Japan Vol. 81., No.1, pp. 41-56, 2003.

Bannu, Suriamiharja. DA, Takeuchi. N, Kuze, H., (2003). Impacts of the ENSO and IOD phenomena: Long-term analysis in Indonesia region.

Behera, S. K., Luo, J.J., Masson, S., Delecluse, P., Gualdi, S., Navarra, A., and Yamagata, T. (2005). Paramount Impact of the Indian Ocean Dipole on the East African Short Rains: A CGCM Study, J. Climate, 18, 4514-4530.

Behera, S.K., Luo, J.J., and Yamagata, T. (2008). The Unusual IOD Event of 2007, Geophy. Res. Letter, 35, L14S11, doi:10.1029/2008GL034122
Saji, N. H., Goswami, B. N., Vinayachandran, P. N., and Yamagata, T. (1999). A dipole mode in the tropical Indian Ocean. Nature, 401, 360-363.

Yamagata, T., Behera, S. K., Luo, J.J., Masson, S., Jury, M. R., and Rao, S. A. (2004). Coupled Ocean-Atmosphere Variability in the Tropical Indian Ocean. AGU Book Ocean-Atmosphere Interaction and Climate Variability, C. Wang, S.-P. Xie and J.A. Carton (eds.), Geophys. Monogr., 147, AGU, Washington D.C., 189-212.

Kailaku, T.E, (2009). Pengaruh ENSO (El Nino-Southern Oscillation) DAN IOD (Indian Ocean Dipole) Terhadap Dinamika Waktu Tanam Padi di Wilayah Tipe Hujan Equatorial dan Monsunal (Studi Kasus Kabupaten Pesisir Selatan, Sumatera Barat dan Kabupaten Karawang, Jawa Barat). Skripsi. Jurusan Meteorologi FMIPA IPB. Bogor.

Widada S., Zakir, A., Yunus S.W., "Kondisi Cuaca Ekstrim di Indonesia Pada Periode Kebakaran Hutan dan Lahan Tahun 1997", Bul. Met. Geo. No.1. Maret 1999, hal:1-11, BMG, Jakarta, 1999.

www.bom.gov.au, diakses tanggal 10 Desember 2013. 